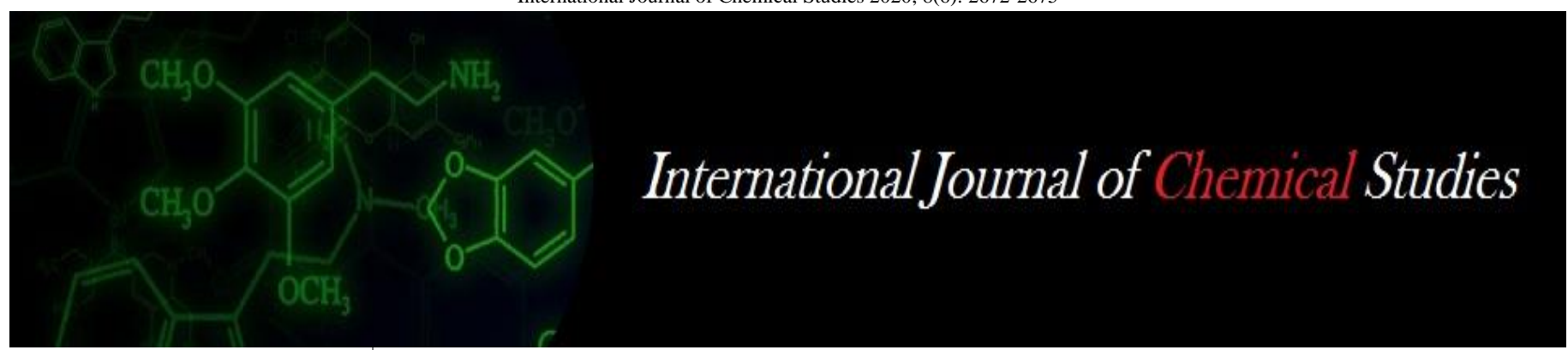

P-ISSN: 2349-8528

E-ISSN: 2321-4902

www.chemijournal.com

IJCS 2020; 8(6): 2672-2675

(C) 2020 IJCS

Received: 16-09-2020

Accepted: 28-10-2020

\section{K Sushma}

Department of Vegetable

Science, College of Horticulture,

SKLTSHU, Hyderabad,

Telangana, India

P Saidaiah

Department of Genetics and

Plant Breeding, College of

Horticulture, SKLTSHU,

Hyderabad, Telangana, India

K Ravinder Reddy

Department of Vegetable

Science, College of Horticulture,

SKLTSHU, Hyderabad,

Telangana, India

\section{S Harikishan}

Department of Plant Pathology, ICRISAT, Patancheru,

Telangana, India

\section{A Geetha}

Department of Crop Physiology, College of Agriculture, PJTSAU Hyderabad, Telangana, India
Corresponding Author:

\section{K Sushma}

Department of Vegetable

Science, College of Horticulture,

SKLTSHU, Hyderabad,

Telangana, India

\section{Studies on genetic variability, heritability and genetic advance in tomato (Solanum lycopersicum L.) genotypes}

\author{
K Sushma, P Saidaiah, K Ravinder Reddy, S Harikishan and A Geetha
}

DOI: https://doi.org/10.22271/chemi.2020.v8.i6al.11186

\begin{abstract}
The present investigation was conducted to generate the information regarding genetic variability, heritability and genetic advance among 23 genotypes. The experiment was laid out during kharif, 2018 in the Randomized Block Design with three replications at P.G research farm, SKLTSHU, Rajendranagar. High analysis of variance (Mean sum of squares for genotype) was recorded for some characters viz., average fruit weight (1236.44), plant height (776.81), number of fruits per plant (360.07), and days to last fruit harvest (208.24) indicated very wide range for these characters. The present study revealed that the phenotypic coefficient of variation was slightly higher than the genotypic coefficient of variation for all the traits. Further, high heritability along with high genetic advance as percent of mean was recorded for number of fruits per plant followed by average fruit weight, fruit yield per plant, number of primary branches per plant, TSS, beta-carotene content, lycopene content, ascorbic acid content, plant height, fruit length and fruit width. These traits are used for direct selection in crop improvement program.
\end{abstract}

Keywords: Tomato, GCV, PCV, heritability, genetic advance

\section{Introduction}

Tomato (Solanum lycopersicum L.) is one of the most important vegetable among solanaceous group. It is native of Peru in South America (Rick, 1969) ${ }^{[18]}$. It is a good source of vitamins and minerals. Tomato is a typical day neutral plant and is mainly self-pollinated, but a certain percentage of cross-pollination also occurs. It is a warm season crop reasonably resistant to heat and drought and grows under wide range of soil and climatic conditions.

The genetic variability is the raw material of vegetable breeding industry on which selection acts to evolve superior genotypes. The higher amount of variation present for a character in the breeding materials, greater is the scope for its improvement through selection. Phenotypic and genotypic coefficients of variation are useful in detecting amounts of variability present in genotypes. Heritability and genetic advance help in determining the influence of environment in expression of characters and the extent to which improvement is possible after selection (Robinson et al., 1949) ${ }^{[19]}$. Heritable variation can be effectively studied in conjunction with genetic advance. High heritability alone is not enough to make efficient selection in segregating generation and needs to be accompanied by a substantial amount of genetic advance (Johnson et al., 1955) ${ }^{[7]}$.

\section{Material and Methods}

The experimental materials for the present investigation comprised to twenty three germplasm of tomato (Table 1) was carried out during kharif, 2018 at P.G research farm, SKLTSHU, Rajendranagar, Hyderabad, Telangana. The experiment was conducted in the Randomized Block Design (RBD) with three replications at spacing of $60 \times 45 \mathrm{~cm}$ per replication. The observations were recorded on viz., plant height $(\mathrm{cm})$, number of primary branches per plant, days to first flowering, days to $50 \%$ flowering, days to first fruit harvest, days to last fruit harvest, number of fruits per plant, fruit length $(\mathrm{cm})$, fruit width $(\mathrm{cm})$, average fruit weight $(\mathrm{g})$, fruit yield per plant $(\mathrm{kg})$, ascorbic acid $(\mathrm{mg} / 100 \mathrm{~g})$, total soluble solids $\left({ }^{\circ}\right.$ Brix), lycopene content $(\mathrm{mg} / 100 \mathrm{~g})$ and beta-carotene $(\mathrm{mg} / 100 \mathrm{~g})$. Phenotypic and genotypic coefficient of variation was estimated according to Burton and De Vane (1953) ${ }^{[4]}$. Heritability and genetic advance were calculated as per formula given by Allard (1960) ${ }^{[1]}$ and Johnson et al., (1955) respectively. 
Table 1: List of twenty three genotypes and their sources

\begin{tabular}{|c|c|c|}
\hline S. No & Genotypes & Source \\
\hline 1. & EC-615055 & NBPGR, Hyderabad \\
\hline 2. & EC-620463 & NBPGR, Hyderabad \\
\hline 3. & EC-620428 & WBPG, Hyderabad \\
\hline 4. & AVTO-1219 Taiwan, China \\
\hline 5. & EC-620378 & NBPGR, Hyderabad \\
\hline 6. & EC-620382 & NBPGR, Hyderabad \\
\hline 7. & EC-620389 & NBPGR, Hyderabad \\
\hline 8. & EC-620395 Hyderabad \\
\hline 9. & EC-620406 & NBPGR, Hyderabad \\
\hline 10. & EC-620427 & NBPGR, Hyderabad \\
\hline 11. & EC-620394 & NBPGR, Hyderabad \\
\hline 12. & EC-620422 & NBPGR, Hyderabad \\
\hline 13. & EC-631369 & NBPGR, Hyderabad \\
\hline 14. & EC-631379 & NBPGR, Hyderabad \\
\hline 15. & EC-620503 & WVC, Taiwan, China \\
\hline 16. & AVTO-9803 & WVC, Taiwan, China \\
\hline 17. & AVTO-9804 & WVC, Taiwan, China \\
\hline 18. & AVTO-1002 & WVC, Taiwan, China \\
\hline 19. & AVTO-0101 & IARI, New Delhi \\
\hline 20. & Pusa Ruby & Periyakulam, TNAU \\
\hline 21. & PKM-1 & GBPUAT, Uttarakhand \\
\hline 22. & Pant bahar & IIHR, Bengaluru \\
\hline 23. & Arka Vikas & \\
\hline
\end{tabular}

\section{Results and Discussion}

\section{Analysis of variance}

The result on analysis of variances (ANOVA) using Randomized block design revealed that the genotypes exhibited highly significant differences for fifteen characters (Table 2). Very high variance (mean sum of squares for genotype) was recorded for some characters viz., average fruit weight (1236.44), plant height (776.81), number of fruits per plant (360.07) and days to last fruit harvest (208.24) indicated very wide range for these characters. This finding was in agreement with the some earlier reports of Singh et al., (2006) ${ }^{[23]}$, Haydar et al., (2007) ${ }^{[5]}$ and Meena et al., (2015) ${ }^{[12]}$.

Table 2: RBD ANOVA for fifteen fruit yield and yield attributes in tomato

\begin{tabular}{|c|c|c|c|c|}
\hline \multirow{2}{*}{ S. No. } & \multirow{2}{*}{ Character } & \multicolumn{3}{|c|}{ Mean sum of squares } \\
\cline { 3 - 5 } & & Replications & Genotypes & Error \\
\hline 1 & Plant height (cm) & 0.01 & $776.81 * * *$ & 23.16 \\
\hline 2 & No. of primary branches per plant & 0.00 & $3.97 * * *$ & 0.08 \\
\hline 3 & Days to first flowering & 0.11 & $27.15 * * *$ & 2.94 \\
\hline 4 & Days to 50\% flowering & 0.05 & $22.64 * * *$ & 4.25 \\
\hline 5 & Days to first fruit harvest & 0.77 & $25.62 * * *$ & 3.41 \\
\hline 6 & Days to last fruit harvest & 0.00 & $208.24 * * *$ & 14.91 \\
\hline 7 & No. of fruits per plant & 0.13 & $360.07 * * *$ & 2.36 \\
\hline 8 & Fruit length (cm) & 0.00 & $1.35 * * *$ & 0.05 \\
\hline 9 & Fruit width (cm) & 0.00 & $1.05 * * *$ & 0.06 \\
\hline 10 & Average fruit weight (g) & 0.02 & $1236.44 * * *$ & 53.62 \\
\hline 11 & Fruit yield/plant (kg) & 0.00 & $0.72 * * *$ & 0.01 \\
\hline 12 & Ascorbic acid content (mg/100g) & 3.06 & $85.23 * * *$ & 1.46 \\
\hline 13 & TSS (0Brix) & 0.00 & $2.29 * * *$ & 0.03 \\
\hline 14 & Lycopene content (mg/100g) & 0.00 & $0.99 * * *$ & 0.02 \\
\hline 15 & Beta-carotene $(\mathrm{mg} / 100 \mathrm{~g})$ & 0.00 & $0.29 * * *$ & 0.00 \\
\hline
\end{tabular}

\section{Phenotypic and genotypic coefficient of variation}

The phenotypic coefficient of variation was recorded from $4.45 \%$ to $38.48 \%$ for different characters. High PCV was observed for number of fruits per plant $(38.48 \%)$ followed by average fruit weight $(34.51 \%)$, fruit yield per plant $(30.62 \%)$, moderate PCV was observed in number of primary branches per plant $(20.89 \%)$, TSS $(20.18 \%)$, beta-carotene content (20.08\%), lycopene content $(19.03 \%)$, ascorbic acid content $(18.99 \%)$, plant height $(18.12 \%)$, fruit length $(15.59 \%)$ and fruit width (13.46\%) (Table 3).

The genotypic coefficient of variation ranged from $3.68 \%$ to $38.11 \%$. High GCV was observed for number of fruits per plant $(38.11 \%)$ followed by average fruit weight $(32.39 \%)$, moderate GCV was observed in fruit yield per plant (29.65\%), number of primary branches per plant $(20.28 \%)$, TSS (19.76\%), beta-carotene content (19.50\%), ascorbic acid content $(18.51 \%)$, lycopene content $(18.37 \%)$, plant height $(17.34 \%)$, fruit length $(14.71 \%)$ and fruit width $(12.32 \%)$. These were in accordance with the findings of Mahesha et al., (2006) ${ }^{[11]}$, Asati et al., (2008) ${ }^{[3]}$, Hedau et al., (2008) [6], Singh (2009) ${ }^{[22]}$, Shashikanth et al., (2010) ${ }^{[20], ~ K u m a r ~ e t ~ a l ., ~}$ (2013) ${ }^{[10]}$, Prajapati et al., (2015) ${ }^{[14]}$, Ullah et al., (2015) ${ }^{[24],}$ Priyanka et al., (2017) ${ }^{[15]}$ and Omkar et al., (2018) ${ }^{[13]}$. 
Table 3: Estimates of mean range, phenotypic and genotypic coefficients of variability, heritability, genetic advance as percent of mean

\begin{tabular}{|c|c|c|c|c|c|c|c|c|}
\hline \multirow{2}{*}{ S. No } & \multirow{2}{*}{ Characters } & \multicolumn{2}{|c|}{ Range } & \multirow{2}{*}{ Mean } & \multirow{2}{*}{$\operatorname{PCV}(\%)$} & \multirow{2}{*}{ GCV $(\%)$} & \multirow{2}{*}{$\mathbf{h}_{2}(\%)$} & \multirow{2}{*}{ GA as per cent of mean } \\
\hline & & Max & Min & & & & & \\
\hline 1 & Plant height $(\mathrm{cm})$ & 63.58 & 133.63 & 91.37 & 18.12 & 17.34 & 91.60 & 34.19 \\
\hline 2 & No. of primary branches per plant & 4.03 & 8.13 & 5.61 & 20.89 & 20.28 & 94.20 & 40.55 \\
\hline 3 & Days to first flowering & 29.30 & 42.33 & 34.05 & 9.74 & 8.34 & 73.30 & 14.71 \\
\hline 4 & Days to $50 \%$ flowering & 32.66 & 44.50 & 38.20 & 8.43 & 6.47 & 59.00 & 10.25 \\
\hline 5 & Days to first fruit harvest & 69.06 & 82.90 & 73.86 & 4.45 & 3.68 & 68.50 & 6.27 \\
\hline 6 & Days to last fruit harvest & 109.06 & 136.56 & 122.32 & 7.28 & 6.56 & 81.20 & 12.18 \\
\hline 7 & No. of fruits per plant & 14.46 & 58.43 & 28.65 & 38.48 & 38.11 & 98.10 & 77.74 \\
\hline 8 & Fruit length $(\mathrm{cm})$ & 3.12 & 5.34 & 4.47 & 15.59 & 14.71 & 89.10 & 28.60 \\
\hline 9 & Fruit width $(\mathrm{cm})$ & 3.47 & 5.94 & 4.67 & 13.46 & 12.32 & 83.70 & 23.23 \\
\hline 10 & Average fruit weight $(\mathrm{g})$ & 33.91 & 110.06 & 61.32 & 34.51 & 32.39 & 88.10 & 62.61 \\
\hline 11 & Fruit yield/plant (kg) & 0.86 & 2.39 & 1.64 & 30.62 & 29.65 & 93.70 & 59.13 \\
\hline 12 & Ascorbic acid content $(\mathrm{mg} / 100 \mathrm{~g})$ & 19.37 & 36.24 & 28.54 & 18.99 & 18.51 & 95.00 & 37.17 \\
\hline 13 & TSS (0Brix) & 3.20 & 7.46 & 4.39 & 20.18 & 19.76 & 95.80 & 39.84 \\
\hline 14 & Lycopene content $(\mathrm{mg} / 100 \mathrm{~g})$ & 2.26 & 3.98 & 3.10 & 19.03 & 18.37 & 93.20 & 36.54 \\
\hline 15 & Beta-carotene $(\mathrm{mg} / 100 \mathrm{~g})$ & 0.83 & 2.16 & 1.59 & 20.08 & 19.50 & 94.40 & 39.04 \\
\hline
\end{tabular}

\section{Heritability $\left(h^{2}\right)$ and Genetic advance}

The investigation revealed that the heritability estimates ranged from 59.00 to $98.10 \%$ for the different characters. High heritability was recorded for number of fruits per plant (98.10\%) followed by TSS $(95.80 \%)$, ascorbic acid content $(95.00 \%)$, beta-carotene content $(94.40 \%)$, number of primary branches per plant $(94.20 \%)$, fruit yield per plant $(93.70 \%)$, lycopene content $(93.20 \%)$, plant height $(91.60 \%)$, fruit length $(89.10 \%)$ and average fruit weight $(88.10 \%)$ (Table 3$)$. The genetic advance in percent of mean varies from $6.27 \%$ to $77.74 \%$ for different characters (Table 3). Highest genetic advance was observed for the number of fruits per plant $(77.74 \%)$ followed by average fruit weight $(62.61 \%)$, fruit yield per plant $(59.13 \%)$, number of primary branches per plant $(40.55 \%)$, TSS $(39.84 \%)$, beta-carotene content (39.04\%), ascorbic acid content (37.17\%), lycopene content $(36.54 \%)$, plant height $(34.19 \%)$, fruit length $(28.60 \%)$ and fruit width $(23.23 \%)$. These were in accordance with the findings of Singh et al., (2006) ${ }^{[23]}$, Asati et al., (2008) ${ }^{[3]}$, Ara et al., (2009) [2], Rahaman et al., (2012) [16], Kumar et al., (2013) ${ }^{[10]}$, Reddy et al., (2013) ${ }^{[17]}$, Khapte and Jansirani (2014) [9], Prajapati et al., (2015) ${ }^{[14]}$, Kaushal et al., (2017) ${ }^{[8]}$ and Shyam et al., (2018) ${ }^{[21]}$.

\section{Conclusion}

Thus, it may be concluded that among twenty three genotypes a wide range of variation was observed. The characters like number of fruits per plant, average fruit weight, fruit yield per plant, number of primary branches per plant, TSS, betacarotene content, ascorbic acid content, lycopene content and plant height are important traits for which selection based on the phenotypic performance could be very effective in improvement of tomato.

\section{References}

1. Allard RW. Principles of Plant Breeding. John Wiley and Sons, Inc. New York 1960,485

2. Ara A, Narayan R, Ahmed N, Khan SH. Genetic variability and selection parameters for yield and quality attributes in tomato. Indian Journal of Horticulture 2009;66:73-78.

3. Asati BS, Rai N, Singh AK. Genetic parameters study for yield and quality traits in tomato. Asian Journal of Horticulture 2008;3:222-225

4. Burton GW, De Vane EW. Estimating heritability in tall fescue (Festuca arundinacea) from replicated clonal material. Proejtunniens 1953;9(22):12-15.
5. Haydar A, Mandal MA, Ahmed MB, Hannan MM, Karim R, Razvy MA et al. Studies on genetic variability and interrelationship among the different traits in tomato (Lycopersicon esculentum Mill.). Middle-East Journal of Science Research 2007;2(3,4):139-142.

6. Hedau NK, Saha S, Singh G, Gahlain A, Mahajan V, Gupta HS. Genetic variability, heritability and correlation study for nutritional quality traits in tomato. Journal of Plant Genetic Resources 2008;21(3):174-178.

7. Johnson HW, Robinson HF, Comstock RE. Estimates of genetic and environmental variability in Soyabean. Agronomy Journal 1955;47:314-318.

8. Kaushal A, Singh A, Chittora A, Nagar L, Yadav RK, Kumawat MK. Variability and Correlation Study in Tomato (Solanum lycopersicum L.). International Journal of Agriculture Sciences 2017;9(29):4391-4394

9. Khapte PS, Jansirani PP. Genetic variability and performance studies of tomato (Solanum lycopersicum L.) genotypes for fruit quality and yield. Trends in Biosciences 2014;7(12):1246-1248

10. Kumar D, Kumar R, Kumar S, Bhardwaj ML, Thakur MC, Kumar R et al. Genetic variability, correlation and path coefficient analysis in tomato. International Journal of Vegetable Science 2013;19(4):313-323.

11. Mahesha DK, Apte UB, Jadhav BB. Genetic variability in tomato (Lycopersicon esculentum Mill.). Research on Crops 2006;7:771-773

12. Meena OP, Bahadur V, Jagtap AB, Saini P, Meena YK. Genetic variability studies of fruit yield and its traits among indeterminate tomato genotypes under open field condition. African Journal of Agril. Research 2015;10:3170-3177

13. Omkar A, Hardyal SK, Subhrajyoti C, Sumit P, Arushi K. Genetic variability, heritability and genetic gain for yield and quality traits in tomato (Solanum lycopersicum L.). International Journal of Chemical Studies 2018;6(5):3095-3098.

14. Prajapati S, Tiwari A, Kadwey S, Jamkar T. Genetic Variability, Heritability and Genetic Advance in Tomato (Solanum Lycopersicon Mill.). International Journal of Agriculture, Environment and Biotechnology 2015;8(2):245-251.

15. Priyanka PL, Vijay B, Pushpa, G. Study on Genetic Variability, Heritability, Genetic Advance in Tomato (Solanum lycopersicum L.). International Journal of Current Microbiology and Applied Sciences 2017;6(11):1775-1783. 
16. Rahaman S, Lakshman SS, Maitr NJ. Genetic variability and heritability studies in tomato (Lycopersicon esculentum Mill.). International Journal of Plant Sciences 2012;7:58-62.

17. Reddy BR, Begum H, Sunil N, Reddy TM. Genetic divergence studies in exotic collections of tomato (Solanum lycopersicum L.). International Journal of Agricultural Sciences 2013;9:588-592.

18. Rick CM. Origin of cultivated tomato, current status of the problem. Abstract XI International Botanical Congress 1969,180.

19. Robinson HF, Comstock RE, Harvey PH. Estimates of heritability and degree of dominance in corn. Agronomy Journal 1949;41:253-259.

20. Shashikanth BN, Patil BC, Salimath PM, Hosamani RM, Krishnaraj PU. Genetic divergence in tomato [Solanum lycopersicum (Mill.) Wettsd.]. Karnataka Journal of Agricultural Sciences 2010;23:538-539.

21. Shyam RK, Solankey SS, Shirin A, Amit K, Ritu K. Genetic studies of wild and cultivated tomato (Solanum lycopersicum L.) genotypes. International Journal of Current Microbiology and Applied Sciences 2018;7:2568-2574.

22. Singh AK. Genetic variability, heritability and genetic advance studies in tomato under cold arid region of Ladakh. Journal of Horticulture 2009;66:400-403.

23. Singh KP, Mandal G, Saha BC. Genetic variability of yield components and biochemical characters in spring season tomato (Lycopersicon esculentum Mill.). Journal of Interacademicia 2006;10:314-318.

24. Ullah MZ, Hassan L, Sonia BS, Patwary AK. Variability and inter relationship studies in tomato (Solanum lycopersicum L.). Journal of Bangladesh Agricultural University 2015;13(1):65-69. 